\section{Evidence of sub-arc mantle oxidation by sulphur and carbon}

A. Rielli ${ }^{*}$, A.G. Tomkins ${ }^{1}$, O. Nebel ${ }^{1}$, J. Brugger ${ }^{1}$,

B. Etschmann', R. Zhong ${ }^{2}$, G.M. Yaxley ${ }^{3}$, D. Paterson ${ }^{4}$

\section{Abstract}

\section{doi: $10.7185 /$ geochemlet. 1713}

The oxygen fugacity $\left(f \mathrm{O}_{2}\right)$ of the Earth's mantle at subduction zones exerts a primary control on the genesis of mineral deposits in the overlying magmatic arcs and on speciation of volcanic gases emitted into the atmosphere. However, the processes governing mantle $\mathrm{fO}_{2}$ such as the introduction of oxidised material by subduction are still unresolved. Here, we present evidence for the reduction of oxidised fluid-borne sulphur and carbon during alteration of depleted mantle by slab fluids at ultra-high pressure in the Bardane peridotite (Western Gneiss Region, Norway). Elevated ferric iron in metasomatic garnet, determined using synchrotron X-ray absorption near edge structure (XANES) spectroscopy, indicates that this process drove oxidation of the silicate assemblage. Our finding indicates that subduction oxidises the Earth's mantle by cycling of sulphur and carbon.

Received 30 June 2016 | Accepted 22 December 2016 | Published 27 January 2017

\section{Letter}

Plate tectonics drives recycling of surface material into the Earth's interior, introducing hydrated and oxidised oceanic lithosphere into the mantle at subduction zones (Wood et al., 1990; Evans, 2012). Fluids liberated during dehydration of subducted crust trigger partial melting of the overlying mantle leading to the formation of volcanic arcs, dominated by oxidised rocks (Ballhaus, 1993; Kelley and Cottrell, 2009). Correlation between oxidation of arc lavas and addition of slab material by aqueous fluids to their mantle source has been quantitatively established (Kelley and Cottrell, 2009; Brounce et al., 2014), indicating that slab

\footnotetext{
1. School of Earth, Atmosphere and the Environment, Monash University, Melbourne, VIC 3800, Australia Corresponding author (email: andrea.rielli@monash.edu)

2. Civil and Environmental Engineering School, University of Science and Technology Beijing, Beijing 100083, China

Research School of Earth Sciences, The Australian National University, Canberra, ACT 2601, Australia
} 4. Australian Synchrotron, 800 Blackburn Road, Clayton, VIC 3168, Australia

fluids are somehow responsible for the observed oxidation. However, although calculations suggest that fluid-borne oxidised sulphur may be important (Evans and Tomkins, 2011), the process has not been resolved with physical evidence Determination of redox processes associated with fluid-mantle interaction cannot be indisputably resolved by studying the product of the arc system (i.e. arc lavas); it is best approached by examining rocks from the deep portion of mantle wedge close to the slab-mantle interface that have been altered by slab fluids, which are preserved as orogenic peridotites.

The Western Gneiss Region of Norway hosts several orogenic peridotite bodies that represent a portion of transition zone mantle that upwelled, melted (Stage M1) and accreted to cratonic lithosphere (Stage M2; Spengler et al., 2006). Subsequently, during the Caledonian orogeny, fluids derived from subducting slab locally promoted metasomatism (Stage M3), as recorded by the Bardane peridotite on Fjørtoft island (Brueckner et al., 2002; Van Roermund et al., 2002; Scambelluri et al., 2008). Other portions have not been infiltrated by slab fluids and preserve the original mantle assemblage (M1-M2), exemplified by the Ugelvik peridotite on the island of Otrøy (Brueckner et al., 2002; Spengler et al., 2006). Although there is debate on the origin of metasomatism at Bardane, the trace element and isotopic signature of the metasomatic assemblage are comparable to the effects of typical subduction zone fluids sensu lato (cf. Brueckner et al., 2002; Scambelluri et al., 2008). The Bardane peridotite represents the best-known analogue for the study of fluid-related redox processes at sub-arc depth.

Previous studies at Bardane focused on a megacrystic garnet-websterite lens (e.g., Brueckner et al., 2002) and showed that interaction between slab fluids and depleted mantle generated metasomatic orthopyroxene, clinopyroxene, spinel, diamond (Van Roermund et al., 2002) and majoritic garnet, which indicate peak conditions of $\sim 6.5 \mathrm{GPa}$ and $800-1000{ }^{\circ} \mathrm{C}$ (M3-3 stage; Scambelluri et al., 2008). Multi-phase solid inclusions (MSI) are hosted in M3 minerals and are thought to have crystallised from slab fluids that permeated the peridotite and contain phlogopite, spinel, amphibole, dolomite, monazite, magnesite, graphite and diamond (Van Roermund et al., 2002; Malaspina et al., 2010).

We found a new occurrence of majoritic garnet as megacrysts in the Bardane peridotite coexisting with clinopyroxene, orthopyroxene, phlogopite and spinel hosted in harzburgitic domains (Fig. 1a). The garnet megacrysts contain sparse exsolved clinopyroxene and orthopyroxene needles (Fig. 1b) with similar size, abundance and distribution to the exsolution previously reported for M3 garnet (Scambelluri et al., 2008). MSI are abundant in the garnet (Fig. 3c). In addition to the previously reported mineralogy (Van Roermund et al., 2002; Malaspina et al., 2010) we found MSI containing phlogopite with barite $\left(\mathrm{BaSO}_{4}\right.$; Figs. 2a, S-1) or magnesite $\left(\mathrm{MgCO}_{3}\right)$, and phosphate minerals (apatite and monazite; Fig. 2b), as well as various multi-silicate inclusions. Single mineral inclusions of pentlandite (Fig. 2c) and graphite (Fig. 2d) also occur. Because of the similarity in mineralogy to that previously reported, this new-found metasomatic assemblage is considered to be equivalent to the M3-3 stage of Scambelluri et al. (2008). 
(a)

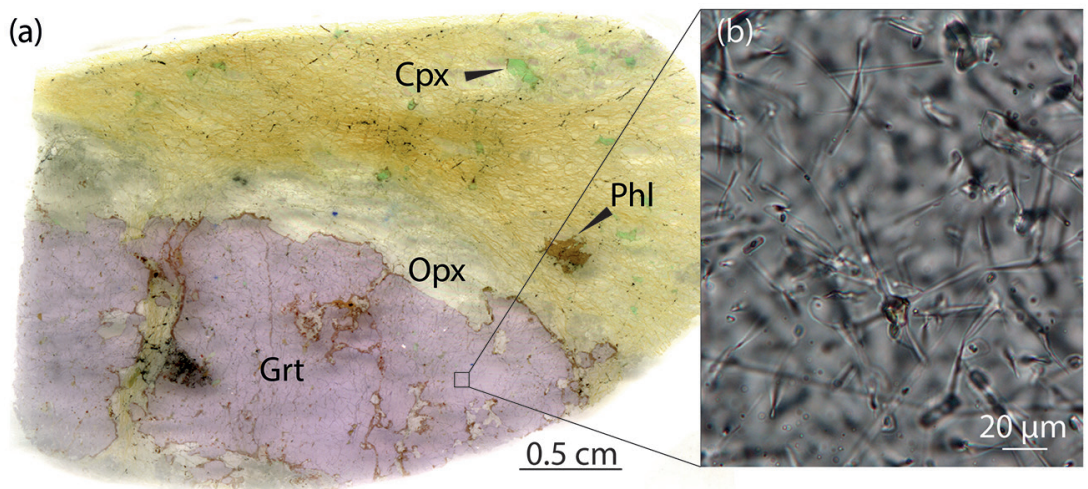

Figure 1 Example of studied metasomatised harzburgite from the Bardane peridotite. (a) Scanned thin section of sample BDN03 showing metasomatic garnet (Grt), orthopyroxene (Opx), phlogopite (Phl) and clinopyroxene (Cpx). (b) Photomicrograph showing exsolved needles of $\mathrm{Cpx}$ and Opx in the garnet crystal, testifying to a majoritic precursor.
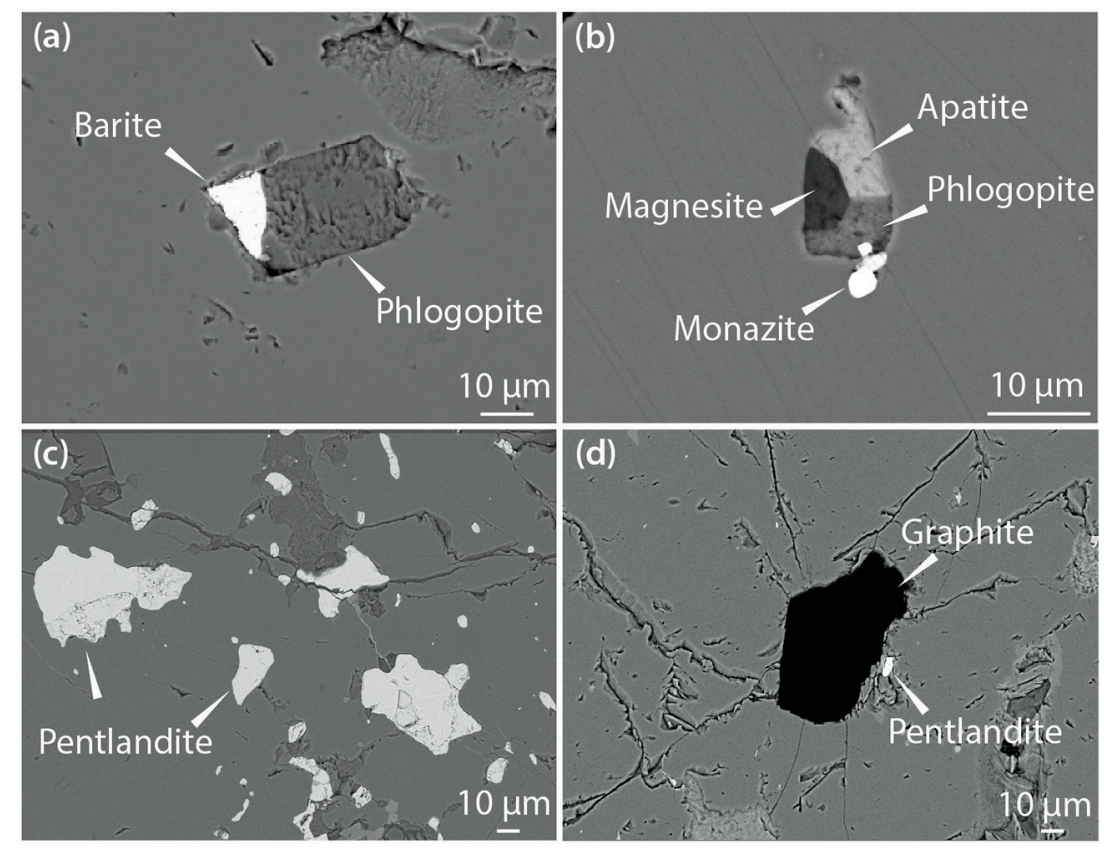

Figure 2 Multi-phase solid inclusions in BDN03 garnet. Back scattered electron (BSE) images showing: (a) MSI containing phlogopite and barite; (b) MSI containing magnesite, phlogopite, apatite and monazite; (c) pentlandite inclusions in garnet; (d) garnet-enclosed graphite.

126 Geochem. Persp. Let. (2017) 3, 124-132 | doi: 10.7185/geochemlet.1713
The Ugelvik peridotite records stages M1 and M2 but has not been affected by later metasomatism (Brueckner et al., 2002; Spengler et al., 2006). Compositional mapping of UGL01 garnet, a garnet megacryst from harzburgitic domain in the Ugelvik peridotite, shows an absence of hydrous minerals or MSI (Fig. 3a). An excess of Si indicates a majoritic component in UGL01 garnet (Table S-1), implying an equilibration pressure of $\sim 7.6 \mathrm{GPa}$ (Supplementary Information).

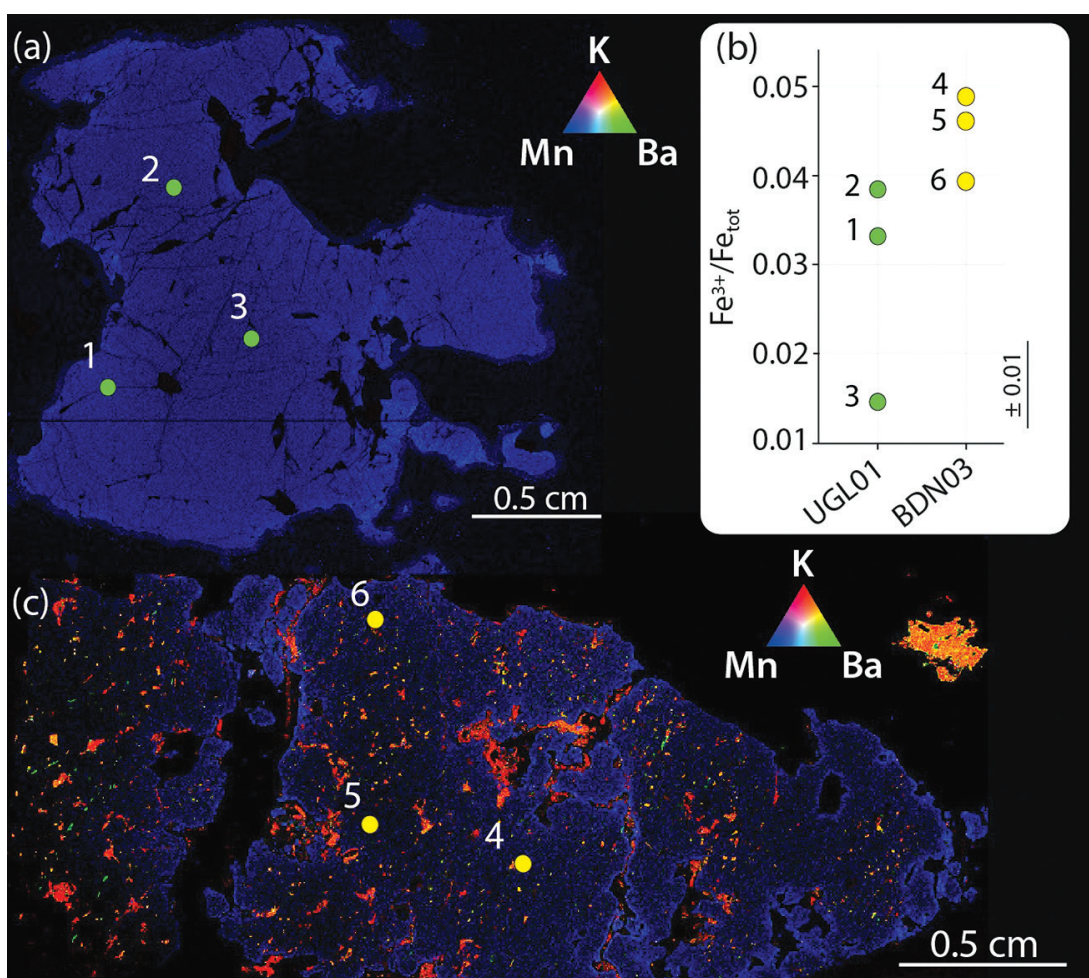

Figure 3 Comparison between metasomatic garnet from Bardane (BDN03) and garnet from Figure 3 Comparison between metasomatic garnet from Bardane (BDNO3) and garnet from tration of K (red; not detected), Ba (green; not detected) and Mn (blue; 0 to $0.46 \mathrm{wt}$. \% $\pm 133 \mathrm{ppm}$ ), indicating a lack of metasomatic minerals. Green spots represent the sites chosen for the acquisition of XANES spectra. (b) Results of XANES analysis comparing the $\mathrm{Fe}^{3+} / \mathrm{Fe}_{\text {tot }}$ ratio in primary garnet in UGL01 with metasomatic garnet in BDN03. Error bar is shown in the lower right hand coner. (c) Compositional map of samplo

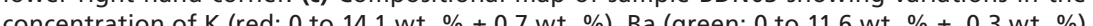

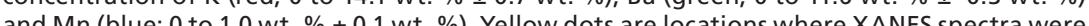
and $\mathrm{Ba}$ (green). The yellow-orange tinted areas highlight the coexistence of barite and phlogopite. 
To investigate whether slab-derived fluids promoted oxidation of depleted mantle through metasomatism at Bardane we measured $\mathrm{Fe}^{3+} / \mathrm{Fe}_{\text {tot }}$ in garnet from Bardane and Ugelvik using XANES spectroscopy (Supplementary Information) Our results show that the metasomatic garnet from Bardane has higher $\mathrm{Fe}^{3+} / \mathrm{Fe}_{\text {tot }}$ compared to the primary garnet from Ugelvik, despite having formed at lower pressure (Fig. 3b; Table S-1; cf. Luth et al., 1990). $\mathrm{Fe}^{3+} / \mathrm{Fe}_{\text {tot }}$ is a proxy for oxidation state such that an increase in $\mathrm{Fe}^{3+} / \mathrm{Fe}_{\text {tot }}$ indicates more oxidising conditions (Berry et al., 2010). Oxygen fugacity $\left(f \mathrm{O}_{2}\right)$ for UGL01 $\left(7.6 \mathrm{GPa} ; 1572{ }^{\circ} \mathrm{C}\right)$, calculated using the Miller et al. (2016) calibration, ranges from $\Delta \log F M Q-6.36$ to -4.75 , and for BDN03 (6.3 GPa; $1000{ }^{\circ} \mathrm{C}$ ) from $\Delta \log$ FMQ -3.47 to -3.16 (Fig. 4; Table S-1; Supplementary Information). It should be noted here that mantle $f \mathrm{O}_{2}$ is not buffered by FMQ, but varies relative to FMQ as a function of pressure via $\mathrm{Fe}^{2+}-\mathrm{Fe}^{3+}$ exchange between olivine, orthopyroxene and garnet (e.g., Miller et al., 2016). Figure 4 shows that the metasomatised sample from Bardane, BDN03, has a higher $\mathrm{fO}_{2}$ compared to a model depleted mantle (Supplementary Information). This relative oxidation implies that metasomatic fluids introduced oxidised species into the harzburgite (cf. Van Roermund et al., 2002; Scambelluri et al., 2008).

Since the MSI are considered to have precipitated from fluids that permeated the peridotite (Van Roermund et al., 2002; Scambelluri et al., 2008), the presence of carbonate and sulphate imply the introduction of oxidised sulphur and carbon during metasomatism. Furthermore, the presence of minerals with reduced sulphur and carbon enclosed in the garnet require that some of the oxidised sulphur and carbon has been reduced to $\mathrm{S}^{2-}$ and $\mathrm{C}^{0}$. At present, there are no experimental data on sulphur speciation at the pressure and temperature recorded by the Bardane peridotite; however, oxidation can be achieved by reduction of any oxidised sulphur species (e.g., $\mathrm{SO}_{4}{ }^{2-}, \mathrm{HSO}_{4}{ }^{-}$or a polysulphide such as $\mathrm{S}_{3}{ }^{-}$) because all require addition of electrons to be reduced to $\mathrm{S}^{2-}$ to form sulphide, as shown by Reaction 1 in the case of sulphate, and Reaction 2 for $\mathrm{S}_{3}{ }^{-}$. Carbon in aqueous fluids at elevated $\mathrm{fO}_{2}$ and neutral $\mathrm{pH}$ is predicted to be predominantly present as $\mathrm{CO}_{2}$ (Sverjensky et al., 2014) and its reduction to form diamond/ graphite is illustrated in Reaction 3. Reduction of oxidised sulphur and carbon to sulphide and graphite require the addition of electrons (Reactions 1, 2 and 3), which must come from other multivalent elements in harzburgite minerals, most likely iron. Metasomatism involving these redox equilibria results in net oxidation of the silicate assemblage by conversion of ferrous iron to ferric iron in newly formed metasomatic minerals such as garnet (Reaction 4).

$$
\begin{gathered}
\mathrm{S}^{6+}+8 \mathrm{e}^{-}=\mathrm{S}^{2-} \text { (sulphide/fluid) } \\
\mathrm{S}_{3}^{-}+5 \mathrm{e}^{-}=3 \mathrm{~S}^{2-} \text { (sulphide/fluid) } \\
\mathrm{C}^{4+}+4 \mathrm{e}^{-}=\mathrm{C}^{0} \text { (diamond) } \\
\mathrm{Fe}^{2+} \text { (olivine/orthopyroxene) }=\mathrm{Fe}^{3+}{ }_{\text {(garnet) }}+1 \mathrm{e}^{-}
\end{gathered}
$$

Reaction 1

Reaction 2

Reaction 3

Reaction 4

The role of carbon as an oxidant at subduction zones has previously been disregarded because the $\mathrm{fO}_{2}$ of the sub-arc mantle was considered to be above the graphite-carbonate buffer; however, the $\mathrm{fO}_{2}$ of the sub-arc mantle has been

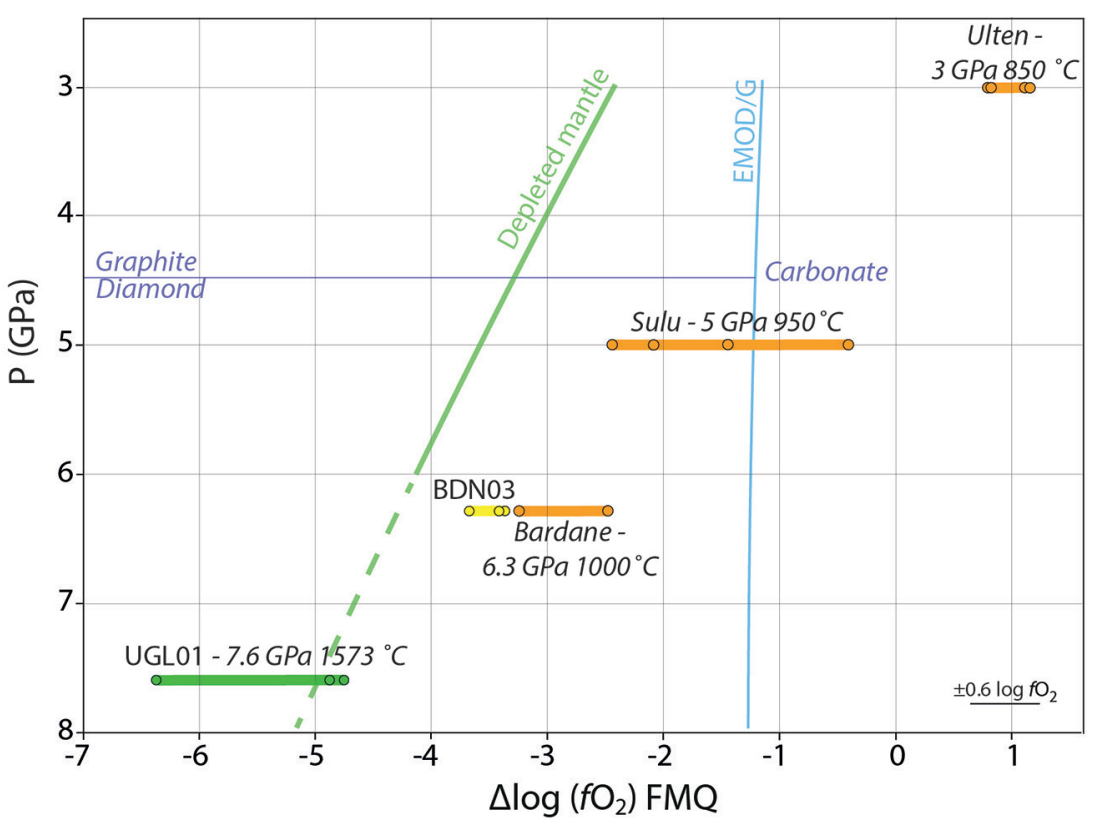

Figure 4 Oxygen fugacity of orogenic peridotites. Variation in $\mathrm{fO}_{2}$ with depth is reported for a model depleted mantle (green line) and the stability of carbonate vs. graphite/diamond is shown by the EMOD/G (blue line). Dashed line is a regression line at pressures where it was not possible to directly calculate $\mathrm{fO}_{2}$. $f \mathrm{O}_{2}$ for UGL01 is represented by green dots and the green bold line represents the variation range. BDN03 $\mathrm{fO}_{2}$ is reported in yellow while in orange is the $\mathrm{O}_{2}$ of metasomatised orogenic peridotites from Malaspina et al. (2009) and Malaspina et al. error bar for the $\mathrm{fO}_{2}$ is reported in the lower right-hand side of the diagram.

inferred from spinel-bearing xenoliths ( $c f$. Evans and Tomkins, 2011) sampling only the shallower portion of the wedge. Geophysical investigations have shown that the depth of the slab-mantle interface below volcanic arcs and the depth of melting lies largely in the garnet stability field (e.g., Syracuse and Abers, 2006). Accordingly, the portion of mantle wedge that can be directly oxidised by slab fluids, i.e. between the slab and the locus of melting, is mainly confined to the garnet stability field. Figure 4 shows that the $\mathrm{fO}_{2}$ of depleted garnetbearing mantle is within the stability field of elemental carbon, delineated by the EMOD/G line (Luth, 1993) for the entire range of depths relevant to direct alteration by slab fluids (Supplementary Information). This implies that $\mathrm{CO}_{2}$ introduced by slab fluids in the deeper mantle wedge will be reduced to graphite/ diamond during fluid-mantle interaction (Reaction 3), promoting oxidation of ferrous iron (Reaction 4). 
Further oxidation can be achieved by reduction of oxidised sulphur, which can increase $\mathrm{fO}_{2}$ above the EMOD/G curve up to the sulphide-sulphate oxygen buffer ( FMQ +2; Mungall, 2002; Jugo et al., 2010). BDN03 and other natural samples from the mantle wedge that have been metasomatised by slab fluids display $\mathrm{fO}_{2}$ values higher than the depleted mantle curve estimated here (Malaspina et al., 2009, 2010) (Fig. 4). The majority of these samples lie in the elemental carbon field, meaning that, contrary to previous suggestions (e.g., Evans and Tomkins, 2011), oxidation of the mantle wedge can be achieved by $\mathrm{C}^{4+}$ reduction alone. However, some samples plot on the right side of the EMOD/G curve, implying that sulphur reduction must have taken place in these cases.

The clear difference in barite content between UGL01 and BDN03 (cf. Figs. S-1, S-2) indicates that the oxidising fluid was also barium-rich. This observation is consistent with the positive correlation between Ba enrichment and oxidation state seen in arc basalts (e.g., Brounce et al., 2014), and combined, these observations hint that barite precipitation may have been tied to the oxidation process. Although barite stability has not been investigated experimentally at high pressure and temperature, $\mathrm{Ba}^{2+}$ is immobile in the presence of $\mathrm{SO}_{4}{ }^{2-}$ at upper crustal conditions, whereas modestly oxidised conditions allow its mobility (more reduced than $1 \log$ unit $\mathrm{fO}_{2}$ below the pyrite-haematite and haematite-magnetite buffers; Hanor, 2000). In the sub-arc mantle, the polysulphide ion, $\mathrm{S}_{3}{ }^{-}$, may be dominant at moderate $\mathrm{fO}_{2}$ conditions (Pokrovski and Dubessy, 2015); the lack of sulphate in solution would allow Ba mobility in typical slab fluids. We suggest that equilibration between $\mathrm{S}_{3}{ }^{-}$and the mantle during metasomatism would allow introduction of Ba via moderately oxidised fluid and formation of both sulphides and barite whilst oxidising $\mathrm{Fe}^{2+}$ to $\mathrm{Fe}^{3+}$ in the silicate assemblage, as illustrated by Reaction 5

$$
\begin{aligned}
& \underset{\text { garnet }}{\mathrm{Ca}_{3} \mathrm{Al}_{2} \mathrm{Si}_{3} \mathrm{O}_{12}}+\underset{\text { olivine }}{7 \mathrm{Fe}_{2}{ }^{2+} \mathrm{SiO}_{4}}+\underset{\text { orthopyroxene }}{3 \mathrm{MgSiO}_{3}}+2 \mathrm{~S}_{3}{ }^{-}+\underset{\text { fluid }}{\mathrm{Ba}^{2+}} \\
& =\underset{\text { garnet }}{\mathrm{Ca}_{3} \mathrm{Fe}_{2}{ }^{3+} \mathrm{Si}_{3} \mathrm{O}_{12}}+\underset{\text { garnet }}{\mathrm{Mg}_{3} \mathrm{Al}_{2} \mathrm{Si}_{3} \mathrm{O}_{12}}+\underset{\text { orthopyroxene sulphide }}{7 \mathrm{FeSiO}}+\underset{\text { barite }}{5 \mathrm{FeS}}
\end{aligned}
$$

Reaction 5

In this redox equilibrium, Reaction 2 is incorporated to modify the garnet-olivineorthopyroxene $\mathrm{fO}_{2}$ buffer defined by Luth et al. (1990), which controls the oxygen fugacity of the garnet-bearing mantle. A comparison between the oxygen fugacity of the Bardane metasomatic assemblage and that of depleted mantle (Fig. 4) shows that Reaction 5 is a feasible mechanism for oxidising the sub-arc mantle. Given that sulphur and carbon are the major redox-sensitive elements in aqueous slab fluids (Evans, 2012), the extent of oxidation achievable by mantle metasomatism is likely to be limited to the sulphide-sulphate transition.

Oxidation of the lower mantle wedge by $\mathrm{CO}_{2}$ reduction is supported by the $\mathrm{C}$ isotope signature of cratonic diamonds, many of which formed during the Archean (Smart et al., 2016), implying that this oxidative process has been ongoing for billions of years. In contrast, S-driven oxidation may have become predominant during the Phanerozoic (Evans and Tomkins, 2011). Therefore, $\mathrm{C}$ may have been more important for long-term redox cycling through arcs, although limiting the magnitude of Precambrian mantle oxidation.
Formation of sulphide through reduction of oxidised sulphur provides a sink for chalcophile elements such as $\mathrm{Cu}$ and $\mathrm{Au}$, which can be carried in slab fluids. Prolonged metasomatism of the sub-arc mantle by slab fluids would thus form hydrated, oxidised and metal-enriched domains. Because sulphur is an order of magnitude more soluble in oxidised basaltic magma (Jugo et al., 2010) melting of these domains generates $\mathrm{H}_{2} \mathrm{O}$-rich and oxidised magma enriched in sulphur and metals. These are characteristics necessary for formation of magmatichydrothermal ore deposits at arcs, such as porphyry $\mathrm{Cu}-\mathrm{Au}$ (Mungall, 2002).

\section{Acknowledgements}

A. Berry is thanked for provision of the garnet standard for the XANES modelling. The authors acknowledge use of facilities within the Monash Centre for Electron Microscopy. Part of this research was undertaken on the X-ray Fluorescence Microscopy beamline at the Australian Synchrotron, Victoria, Australia. K. Evans and E. Cottrell are thanked for their constructive comments that helped to improve the manuscript. This research was funded by a Monash Research Accelerator Grant to A. Tomkins and by a Society of Economic Geologists (SEG) student research grant to A. Rielli. O. Nebel was supported through an ARC DECRA fellowship (DE120100513).

Editor: Graham Pearson

\section{Additional Information}

Supplementary Information accompanies this letter at www.geochemical perspectivesletters.org/article1713

Reprints and permission information are available online at http://www. geochemicalperspectivesletters.org/copyright-and-permissions

Cite this letter as: Rielli, A., Tomkins, A.G., Nebel, O., Brugger, J., Etschmann, B. Zhong R, Yaxley, G.M, Paterson, D. (2017) Evidence of sub-arc mantle oxidation by sulphur and carbon. Geochem. Persp. Let. 3, 124-132.

\section{References}

BALLHAUS, C. (1993) Redox states of lithospheric and asthenospheric upper mantle. Contributions to Mineralogy and Petrology 114, 331-348.

BerRY, A.J., YAXLEY, G.M., WOODLAND, A.B., ForAN, G.J. (2010) A XANES calibration for determining the oxidation state of iron in mantle garnet. Chemical Geology 278, 31-37.

Brounce, M N KeLLY, K. A. COTTRELL, E (2014) Variations in Fe3+/ Fe of Mariana Arc basalts and mantle wedge $\mathrm{fO}_{2}$. Journal of Petrology 55, 2513-2536. 
BrueCKNER, K.H., CARSwell, D.A., GRIFFin, W.L. (2002) Paleozoic diamonds within a Precambrian peridotite lens in UHP gneisses of the Norwegian Caledonides. Earth and Planetary Science Letters 203, 805-816.

EvANS, K.A. (2012) The redox budget of subduction zones. Earth-Science Reviews 113, 11-32.

EVANS, K.A., TomKINS, A.G. (2011) The relationship between subduction zone redox budget and arc magma fertility. Earth and Planetary Science Letters 308, 401-409.

HANOR, J.S. (2000) Barite-Celestine Geochemistry and Environments of Formation. Reviews in Mineralogy and Geochemistry 40, 193-275.

Jugo, P.J., WiLKE, M., BotCHARNIKOV, R.E. (2010) Sulfur K-edge XANES analysis of natural and synthetic basaltic glasses: Implications for $\mathrm{S}$ speciation and $\mathrm{S}$ content as function of oxygen fugacity. Geochimica et Cosmochimica Acta 74, 5926-5938.

Kelley, K.A., CotTrell, E. (2009) Water and oxidation state of subduction zone magmas. Science 325, 605-607.

LUTH, R.W. (1993) Diamonds, Eclogites, and the oxidation state of the Earth's mantle. Science 261, $66-68$.

LuTH, R.W., VIRGO, D., BOYD, F.R., WOOD, B.J. (1990) Ferric iron in mantle-derived garnets. Contributions to Mineralogy and Petrology 104, 56-72.

Malaspina, N., Poli, S., Fumagalli, P. (2009) The Oxidation State of Metasomatized Mantle Wedge: Insights from C-O-H-bearing Garnet Peridotite. Journal of Petrology 50, 1533-1552.

Malaspina, N., Scambelluri, M., Poli, S., Van Roermund, H.L.M., Langenhorst, F. (2010) The oxidation state of mantle wedge majoritic garnet websterites metasomatised by C-bearing The oxidation state of mantle wedge majoritic garnet websterites metas
subduction fluids. Earth and Planetary Science Letters 298, 417-426.

Miller, W.G.R., Holland, T.J.B., GibSON, S.A. (2016) Garnet and Spinel Oxybarometers: New Internally Consistent Multi-equilibria Models with Applications to the Oxidation State of the Lithospheric Mantle. Journal of Petrology 57, 1199-1222.

MungaLL, E.J. (2002) Roasting the mantle: Slab melting and the genesis of major $\mathrm{Au}$ and $\mathrm{Au}$-rich $\mathrm{Cu}$ deposits. Geology 30, 915-918.

POKROVSKI, G.S., DuBESSY, J. (2015) Stability and abundance of the trisulfur radical ion S3- in hydrothermal fluids. Earth and Planetary Science Letters 411, 298-309.

Scambelluri, M., PetTKe, T., VAn Roermund, H.L.M. (2008) Majoritic garnets monitor deep subduction fluid flow and mantle dynamics. Geology 36, 59-62.

Smart, K.A., TAppe, S., Stern, R.A., Webb, S.J., Ashwal, L.D. (2016) Early Archaean tectonics and mantle redox recorded in Witwatersrand diamonds. Nature Geoscience 9, 255-259.

Spengler, D., van Roermund, H.L., Drury, M.R., Ottolini, L., Mason, P.R., Davies, G.R (2006) Deep origin and hot melting of an Archaean orogenic peridotite massif in Norway. Nature 440, 913-17.

SVERJENSKY, D.A., STAGNO, V., HUANG, F. (2014) Important role for organic carbon in subductionzone fluids in the deep carbon cycle. Nature Geoscience 7, 909-913.

SYRACUSE, E.M., ABERS, G.A. (2006) Global compilation of variations in slab depth beneath arc volcanoes and implications. Geochemistry, Geophysics, Geosystems 7, 1-18.

Van Roermund, H.L.M., Carswell, D.A., Drury, M.R., Heijboer, T.C. (2002) Microdiamonds in megacrystic garnet websterite pod from Bardane on the island of Fjortft, western Norway: Evidence for diamond formation in mantle rocks during deep continental subduction. Geology 30, 959-962.

Wood, B.J., BRYNDZIA, L.T., JoHnson, E.K. (1990) Mantle oxidation state and its relationship to tectonic environment and fluid speciation. Science 248, 337-345. 